\title{
Data on Observation Wells, Ground-Water Levels, and Ground-Water Quality for the Stratified-Drift Aquifer in the Northwestern Basin of Country Pond, Kingston, New Hampshire
}

\section{BY PETER J. STEKL}

U.S. GEOLOGICAL SURVEY

Open-File Report 93-658

Prepared in cooperation with the

U.S. ENVIRONMENTAL PROTECTION AGENCY REGION I, WASTE MANAGEMENT DIVISION

and the

NEW HAMPSHIRE DEPARTMENT OF ENVIRONMENTAL SERVICES, WASTE MANAGEMENT DIVISION

Bow, New Hampshire

1994 


\title{
U.S. DEPARTMENT OF THE INTERIOR BRUCE BABBITT, Secretary
}

\author{
U.S. GEOLOGICAL SURVEY \\ GORDON P. EATON, Director
}

\footnotetext{
Any use of trade, product, or firm names in this publication is for descriptive purposes only and does not imply endorsement by the U.S. Government.
}

For additional information write to:

District Chief

U.S. Geological Survey

NH/VT District

525 Clinton Street

Bow, NH 03304
Copies of this report may be purchased from:

Earth Science Information Center

Open-File Reports Section

Box 25425, Mail Stop 517

Federal Center

Denver, Colorado 80225-0425 


\section{CONTENTS}

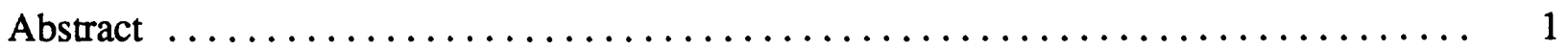

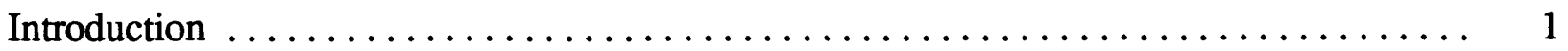

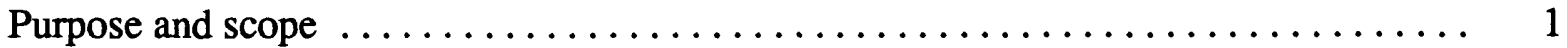

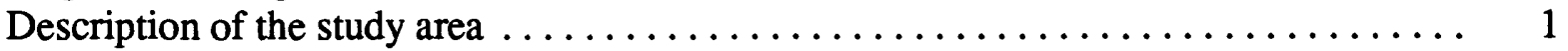

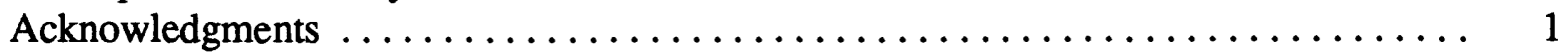

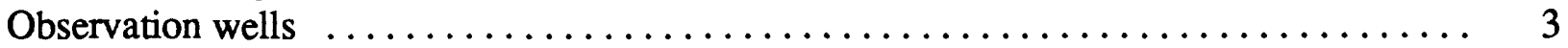

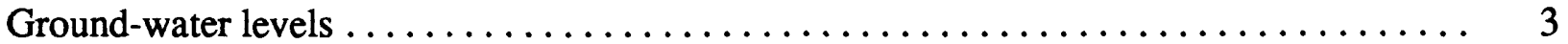

Ground-water quality $\ldots \ldots \ldots \ldots \ldots \ldots \ldots \ldots \ldots \ldots \ldots \ldots \ldots \ldots \ldots \ldots \ldots \ldots, \quad 5$

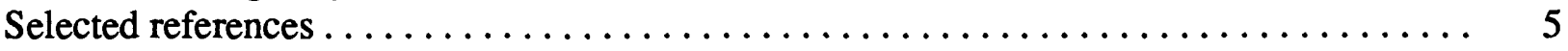

\section{ILLUSTRATIONS}

1. Map showing the location of the study area $\ldots \ldots \ldots \ldots \ldots \ldots \ldots \ldots \ldots 2$

2. Map showing the locations of wells in Country Pond, Kingston, New Hampshire ... 4

\section{TABLES}

1. Description of two wells drilled in October 1983 in Country Pond, Kingston,

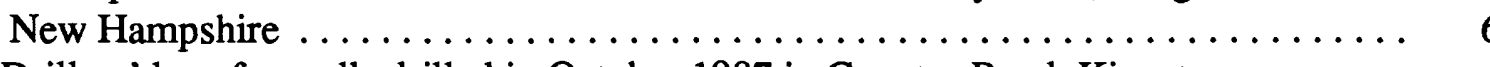

2. Drillers' logs for wells drilled in October 1987 in Country Pond, Kingston,

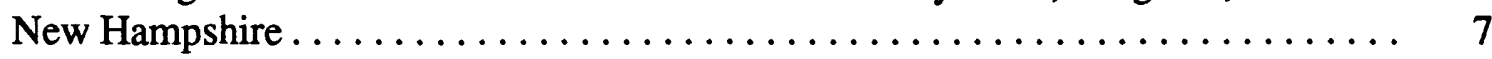

3. Drillers' logs for wells drilled in November 1988 in Country Pond, Kingston, New Hampshire ................................ 10

4. Drillers' logs for wells drilled in May 1991 in Country Pond, Kingston, New Hampshire

5. Results of ground-water-quality analyses of samples from wells constructed in October 1987 in Country Pond, Kingston, New Hampshire

6. Results of ground-water-quality analyses of samples from wells constructed in November 1988 at Country Pond, Kingston, New Hampshire ........... 16

7. Results of ground-water-quality analyses of samples from wells constructed in May 1991 at Country Pond, Kingston, New Hampshire ................

8. Results of ground-water quality analyses for two wells sampled at Country Pond, Kingston, New Hampshire 
CONVERSION FACTORS AND VERTICAL DATUM

\begin{tabular}{lcl}
\hline Multiple & By & To obtain \\
\hline & Length & \\
inch (in.) & 25.4 & millimeter \\
foot (ft) & 0.3048 & meter \\
mile (mi) & 1.609 & kilometer \\
& Area & \\
square mile (mi) & 2.590 & square kilometer \\
acre & 4,047 & square meter \\
& Volume & \\
gallon (gal) & 3.785 & liter \\
& Flow & \\
gallon per minute (gal/min) & 0.06309 & liter per second \\
gallon per day (gal/d) & 3.7854 & liter per day \\
\hline
\end{tabular}

Sea level: In this report, "sea level" refers to the National Geodetic Vertical Datum of 1929--a geodetic datum derived from a general adjustment of the first-order level nets of both the United States and Canada, formerly called Sea Level Datum of 1929. 


\title{
Data on Observation Wells, Ground-Water Levels, and Ground-Water Quality for the Stratified-Drift Aquifer in the Northwestern Basin of Country Pond, Kingston, New Hamp- shire
}

\author{
By Peter J. Stekl
}

\begin{abstract}
This report presents data on ground-water levels and quality collected for a study of ground-water contamination in stratified drift at Country Pond in Kingston, New Hampshire. The data were collected in 1987, 1988, and 1991 in cooperation with the U.S. Environmental Protection Agency and the New Hampshire Department of Environmental Services, Waste Management Division.

Water-quality analyses are presented for 56 samples collected from 30 wells installed at various depths in stratified drift beneath Country Pond. Water-level data are also presented for nine wells drilled in 1991. Samples were analyzed in the laboratory for 40 volatile organic compounds. Ground-water contamination from volatile organic compounds was found in 23 of the 56 samples collected.
\end{abstract}

\section{INTRODUCTION}

This study was initiated in 1987 to provide data needed to address the fate of contamination flowing downgradient from a hazardous waste site in Kingston, N.H. The areas examined included Country Pond and the stratified-drift aquifer bordering and underlying the pond. The study was done in cooperation with the U.S. Environmental Protection Agency (USEPA), Region I, Waste Management Division and the New Hampshire Department of Environmental Services, Waste Management Division (NHDES, WMD).

\section{Purpose and Scope}

The purpose of this report is to present selected data on observation wells, ground-water levels, and ground-water quality from wells drilled at Country Pond in 1987, 1988, and 1991. The report includes data on well construction, well yields, head relations between ground water and the pond, and ground-water quality. Additional ground-water-level and ground-water-quality data are also provided for two wells drilled in 1983 by a private consulting firm at the northern and western edge of the pond.

Contaminants originating from a hazardouswaste site in the town of Kingston enter surface and ground water and flow southeasterly from the site through and beneath a wetland toward Country Pond (fig. 1). Previous investigations by the USEPA (1986); Goldberg-Zoino and Associates (1986); and Ecology and Environment, Inc. (1982) were limited to field explorations of the site area and to the wetland southeast of the site.

\section{Description of the Study Area}

The 14-acre study area is the northwestem part of Country Pond (fig. 1) and encompasses about 5 percent of the pond area. Ground-water contamination originated approximately $1,500 \mathrm{ft}$ northwest of the study area and extends from the source through a wetland and into the study area. The primary contaminants found in ground water downgradient from the site are volatile organic compounds (VOC's) of arsenic, and nickel (Goldberg-Zoino and Associates, 1986).

\section{Acknowledgments}

Appreciation is expressed to town officials in Kingston and to private residents along the shore of Country Pond who granted the author access to the pond through their properties. Appreciation is also extended to private consultants who made their reports and drilling logs available to the author. 


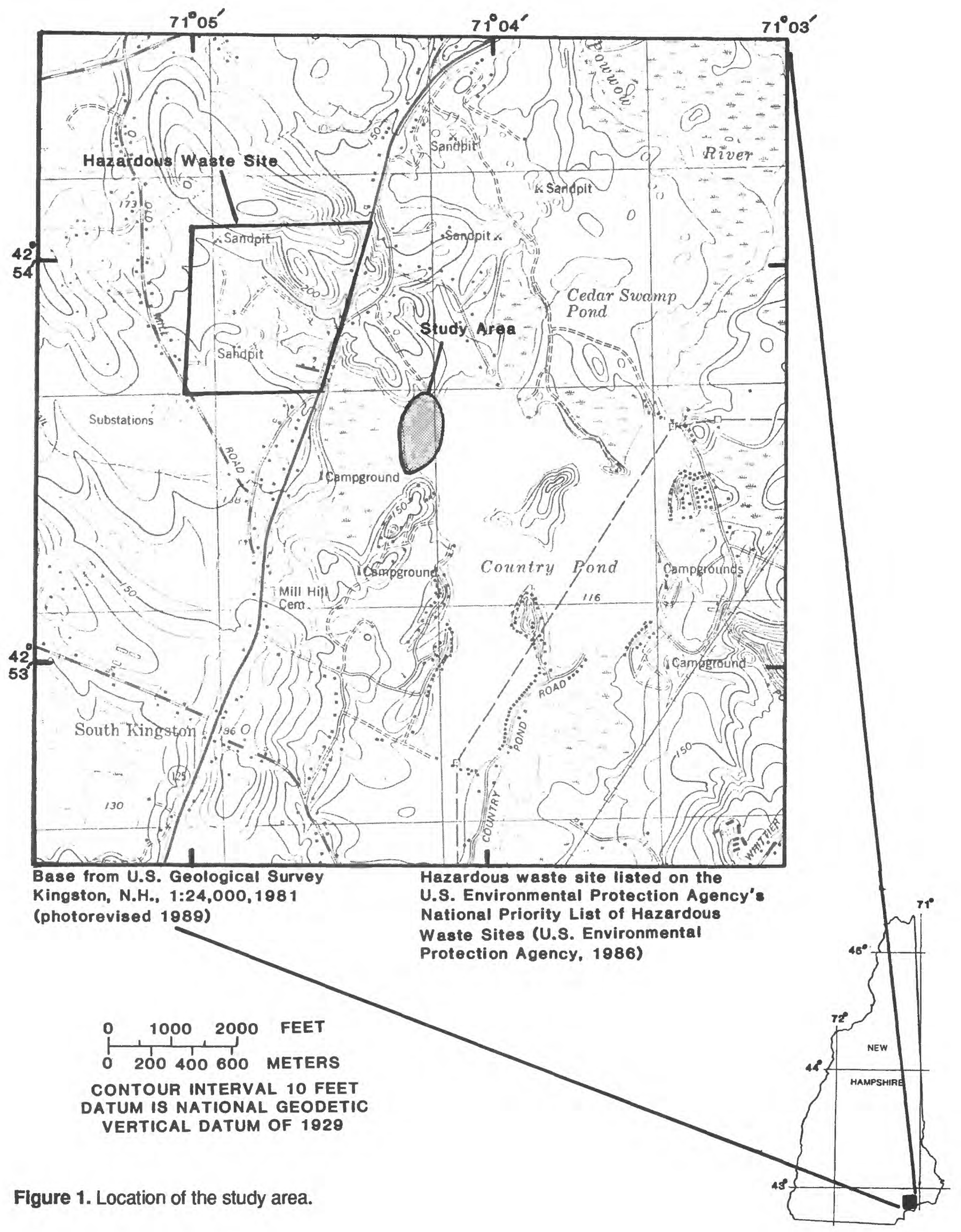




\section{OBSERVATION WELLS}

Observation wells were installed beneath the pond bottom in 1987, 1988, and 1991 (fig. 2) to determine water levels and to collect water-quality samples. Wells installed in 1987 were left in place over the winter, whereas wells installed in 1988 and 1991 were removed within 24 hours of installation. All wells were installed and sampled before pond levels were lowered in the autumn.

Thirty wells were installed at various depths in stratified drift underlying Country Pond. Depths to refusal measured from pond bottom ranged from 11.3 to $60.8 \mathrm{ft}$ with an average of $31.3 \mathrm{ft}$.

During October 1987, 11 wells were installed at 7 locations. At four locations, two wells were installed and screened in the stratified-drift aquifer at intervals separated by about $10 \mathrm{ft}$. The wells were originally intended to serve as temporary monitoring sites that would be in place for about 1 year. After installation, the wells were marked with florescent orange paint and an arc of buoys was strung across the eastern edge of the well network as a warning to boats. Two sets of ground-water samples (October 1987 and February 1988) were collected and analyzed from these wells by the NHDES, WMD. When the wells were damaged by winter ice, no subsequent samples were taken. The wells were removed in June 1988 by the NHDES, WMD.

Drilling methods in November 1988 and May 1991 differed slightly from the methods used in 1987. In 1988 and 1991, the wells were installed, developed, sampled, and then immediately removed so that the pond was clear of all well casings and screens at the end of a day's drilling. This procedure was adopted to minimize damage to the wells and reduce interference with the recreational use of the pond. Ground-water samples were collected at intervals of 5 to $10 \mathrm{ft}$ as each well point was advanced.
All wells were installed by use of a tripod hammer-weight system to drive $11 / 4$-in. galvanized (steam-cleaned) well points from a floating platform. Well-site locations were chosen by the USEPA and the NHDES, WMD. Well construction and measurements of well yield and potentiometric heads were supervised by the U.S. Geological Survey (USGS) for wells drilled in 1987 and 1991 and by the NHDES, WMD for wells drilled in 1988. Surveying and ground-water sampling was supervised by the NHDES, WMD.

A subcontract was issued to a local well drilling company for pipe cleaning, well construction, and well development and removal. The New Hampshire Department of Transportation provided a 16 - by $16-\mathrm{ft}$ floating platform for drilling. Wells were developed by use of a hand-pitcher pump until yield stabilized and water was free of sediment. Final well yields were estimated volumetrically by use of a centrifugal pump and a 5-gallon bucket. Single and multi-level wells were installed to the depth at which maximum well yields were achieved. An average of two wells were installed, sampled, and removed each day. Drillers' logs for wells are given in tables 1, 2, 3 , and 4. Table 1 contains logs made previously by a consultant for two wells installed on the northern and western edge of the pond in 1983. Tables 2, 3, and 4 include logs for wells constructed as described in this section in 1987,1988 , and 1991, respectively. Well yields were measured at observation wells in 1987 and 1991 and varied from 0 to $60 \mathrm{gal} / \mathrm{min}$ (tables 2 and 4)

\section{GROUND-WATER LEVELS}

Water levels were measured at several depths in nine wells drilled in 1991 (table 4). Ground-water and pond levels were measured with an electric tape accurate to $+0.01 \mathrm{ft}$. All ground-water and pond levels at a given well site are referenced to a common datum plane such that comparisons between water levels 


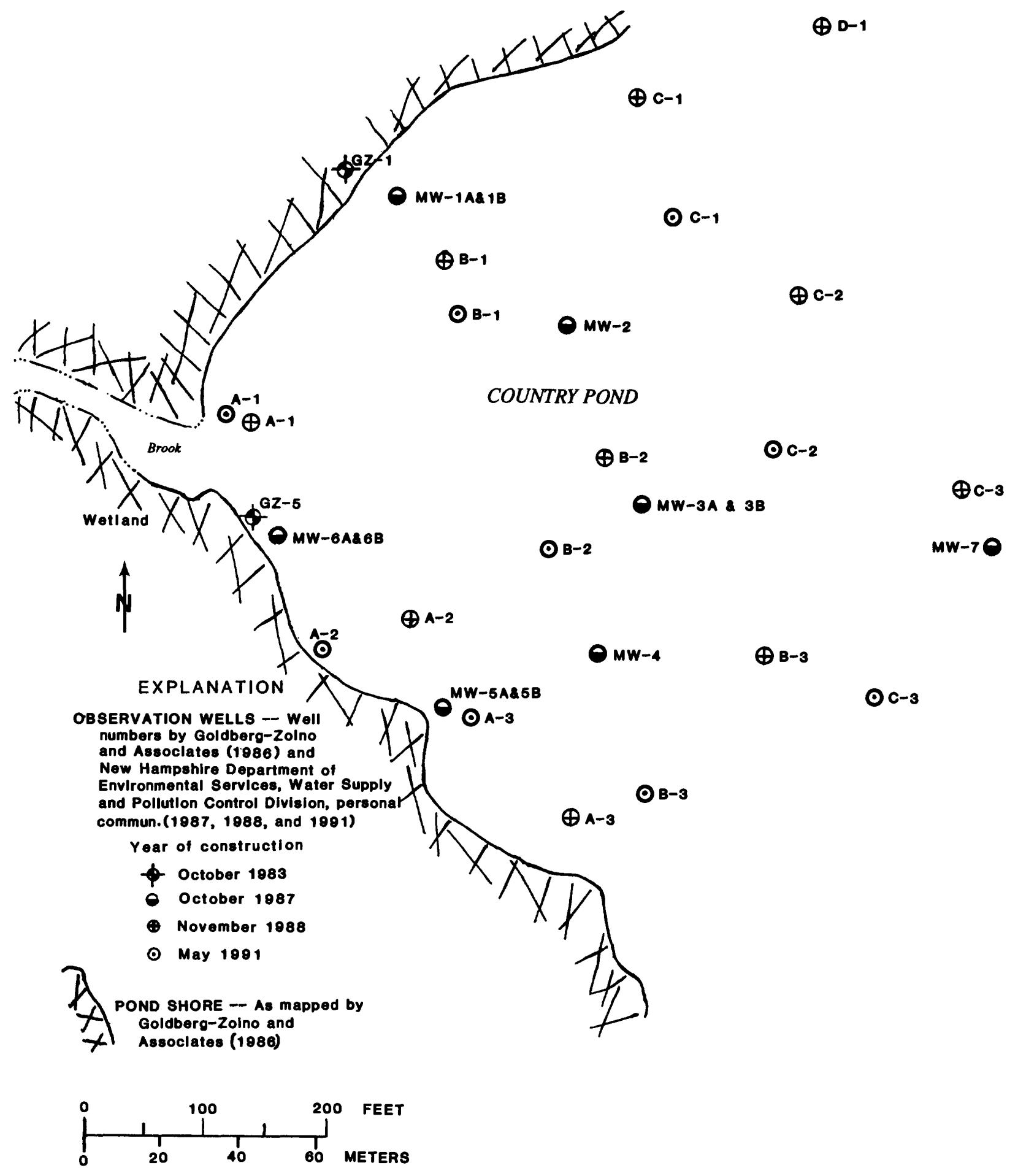

Figure 2. Locations of wells in Country Pond, Kingston, New Hampshire. 
are significant to $+0.01 \mathrm{ft}$. Water levels in wells were stabilized to ambient conditions after completion of well development. Water levels were considered stabilized when two consecutive measurements, separated by 15 minutes, showed less than a $0.01 \mathrm{ft}$ head change. Differences in levels between the pond and ground water indicate high hydraulic heads in the stratified-drift aquifer at all measured well sites (table 4).

\section{GROUND-WATER QUALITY}

Ground-water quality samples were taken in 1987, 1988, and 1991 from wells drilled in the study area. Seventeen ground-water samples from 11 wells drilled in October 1987 were collected in October 1987 and February 1988. Nineteen ground-water samples from 10 wells drilled in November 1988 were collected in November 1988, and 20 groundwater samples from 9 wells drilled in May 1991 were collected in May 1991.

After well development, water samples were collected from each well for analysis of VOC's by use of a stainless steel bailer. Standard quality assurance and quality-control procedures were followed in the collection and analysis of samples. All water samples were analyzed by the NHDES laboratory in Concord, N.H. and the results of the analyses are given in tables 5, 6, and 7. Additional ground-water-quality data for two wells installed on the north and west edge of the pond are given in table 8. Detected VOC's include chloroethane; 1,1 -dichloroethane; 1,2 -dichloroethane; c\&t-1,2-dichloroethylene; benzene; ethyl benzene; xylene; cillorobenzene; dichlorobenzenes; tetrahydro-furan; and diethyl ether (tables 5, 6, and 7). Concentrations of total VOC's (sum of analytes) in the wells that were sampled ranged from 0.0 to $1,300 \mathrm{ppb}$ (parts per billion).

\section{SELECTED REFERENCES}

Ecology and Environment, Inc., 1982, Field investigations of uncontrolled hazardous waste sites, FIT Project, hydrogeologic investigation, Kingston, New Hampshire: U.S. Environmental Protection Agency, Task Report, contract no. 68-016056.

GeoTrans, Inc., 1986, Analysis of groundwater flow and chemical transport from the Ottati and Goss/Great Lakes Container Corporation Sites: U.S. Environmental Protection Agency, Expert Report.

Goldberg-Zoino and Associates, 1986, Remedial investigation of the Ottati and Goss/ Great Lakes Container Corporation site, Kingston, New Hampshire: Concord, N.H., New Hampshire Department of Environmental Services, Water Supply and Pollution Control Division, $229 \mathrm{p}$.

U.S. Environmental Protection Agency, 1986, Amendment to national oil and hazardous substance contingency plan, national priorities list--final rule and proposed rules: Federal Register, v. 51, no. 111, p. 21053-21112. 


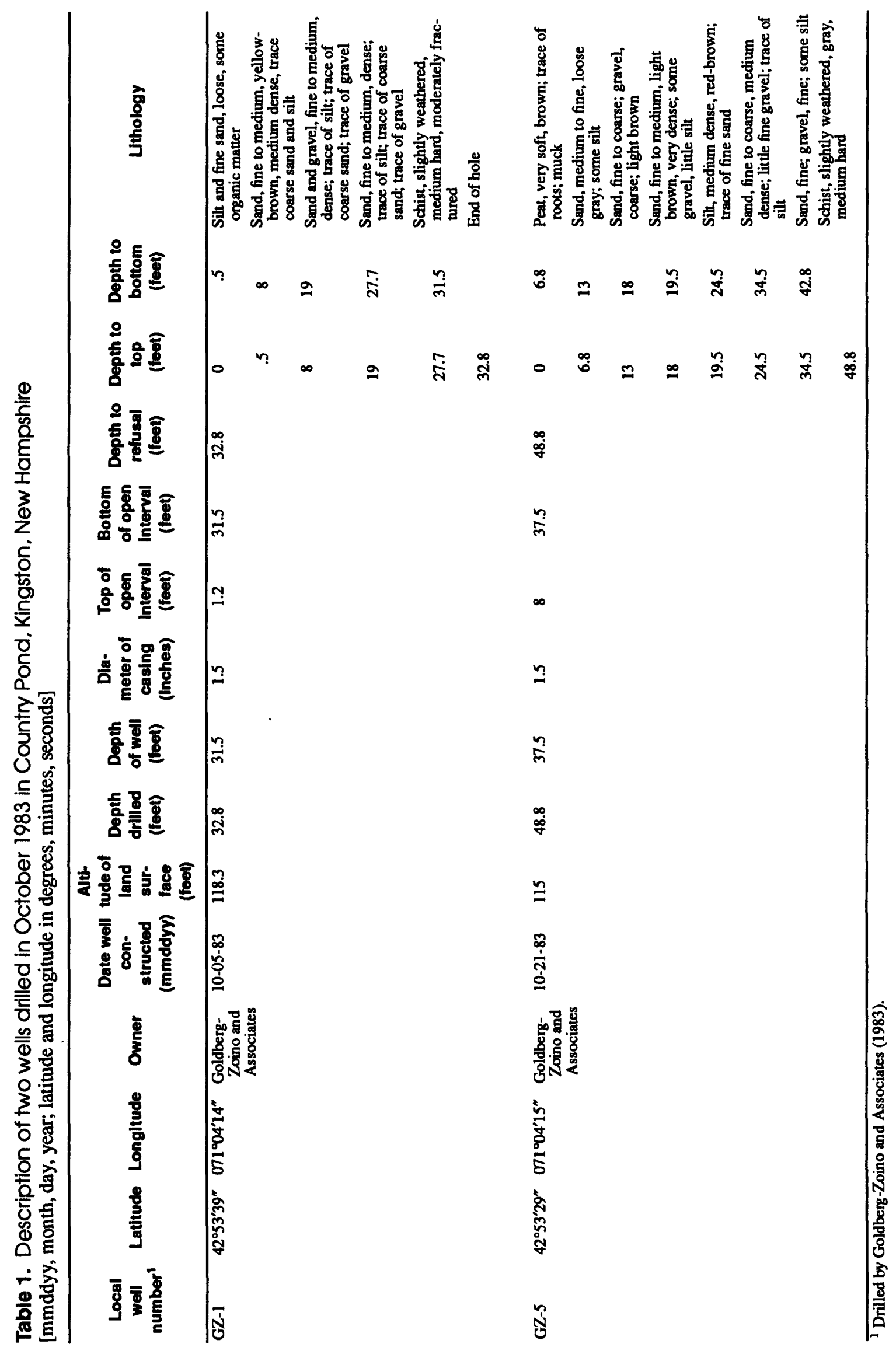




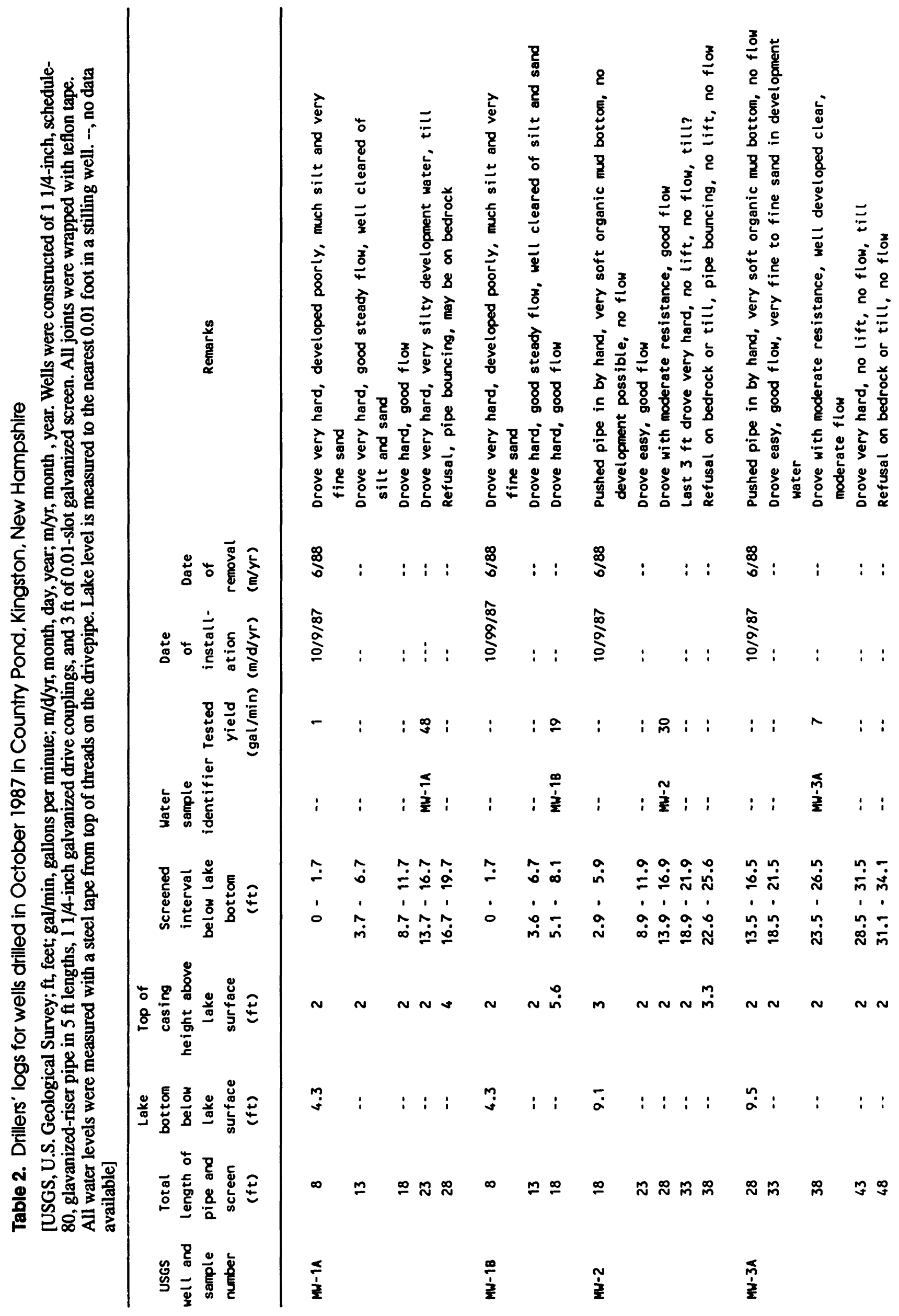




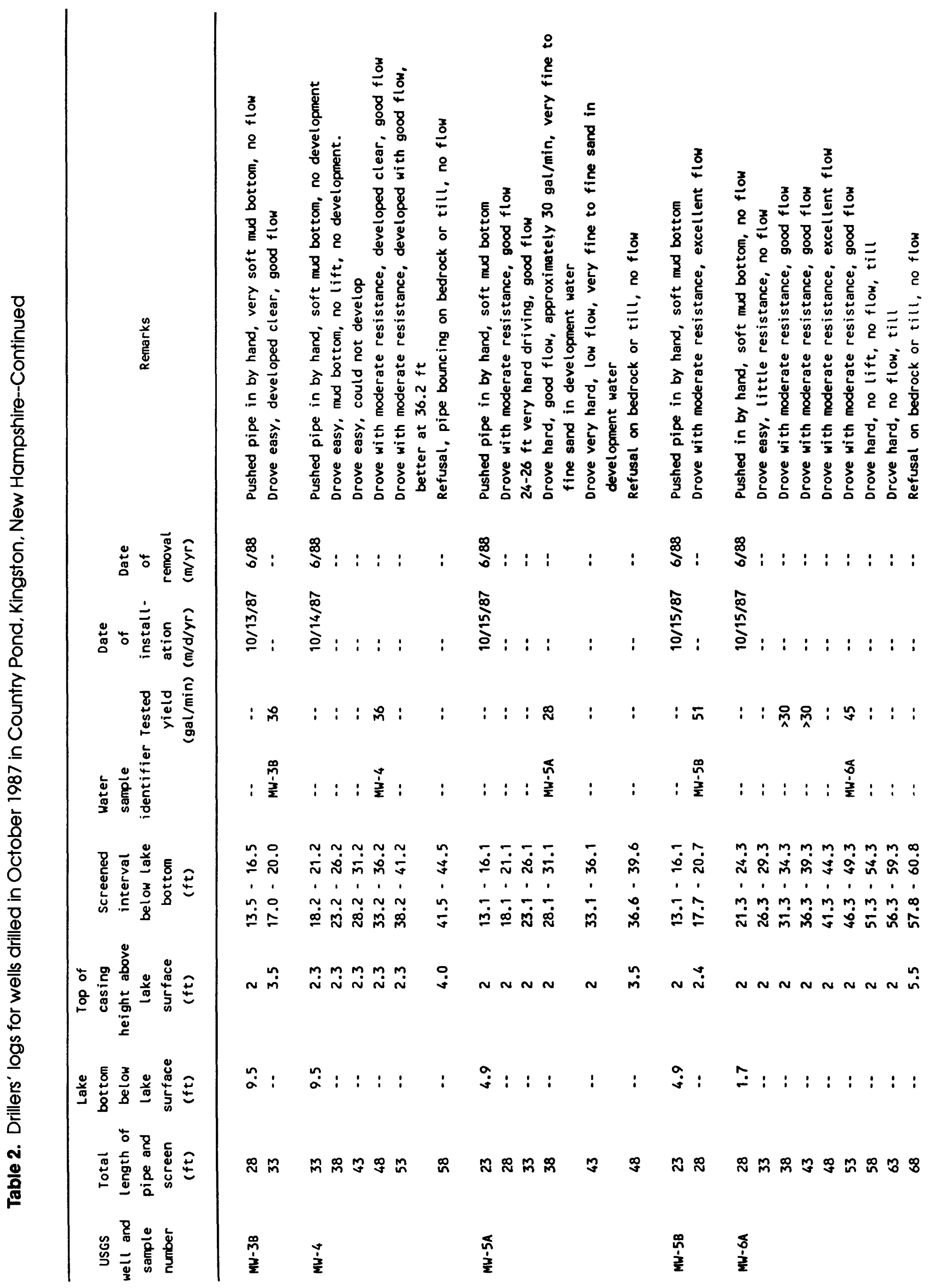




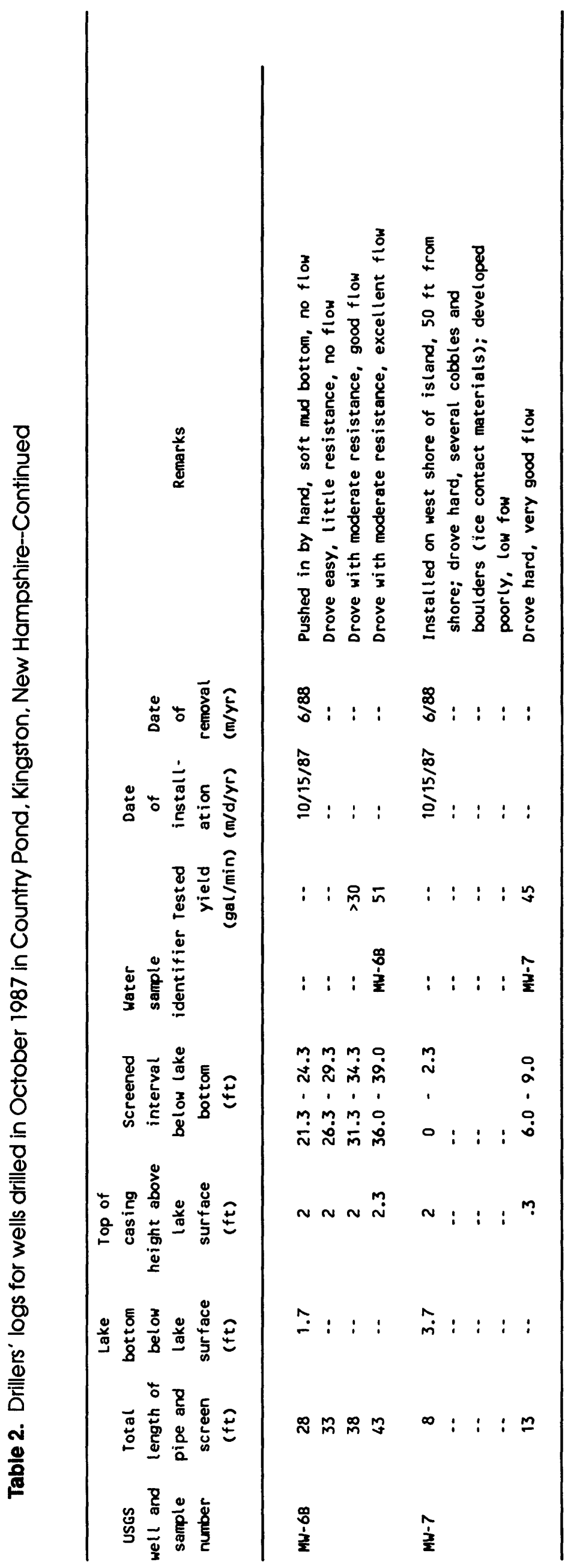




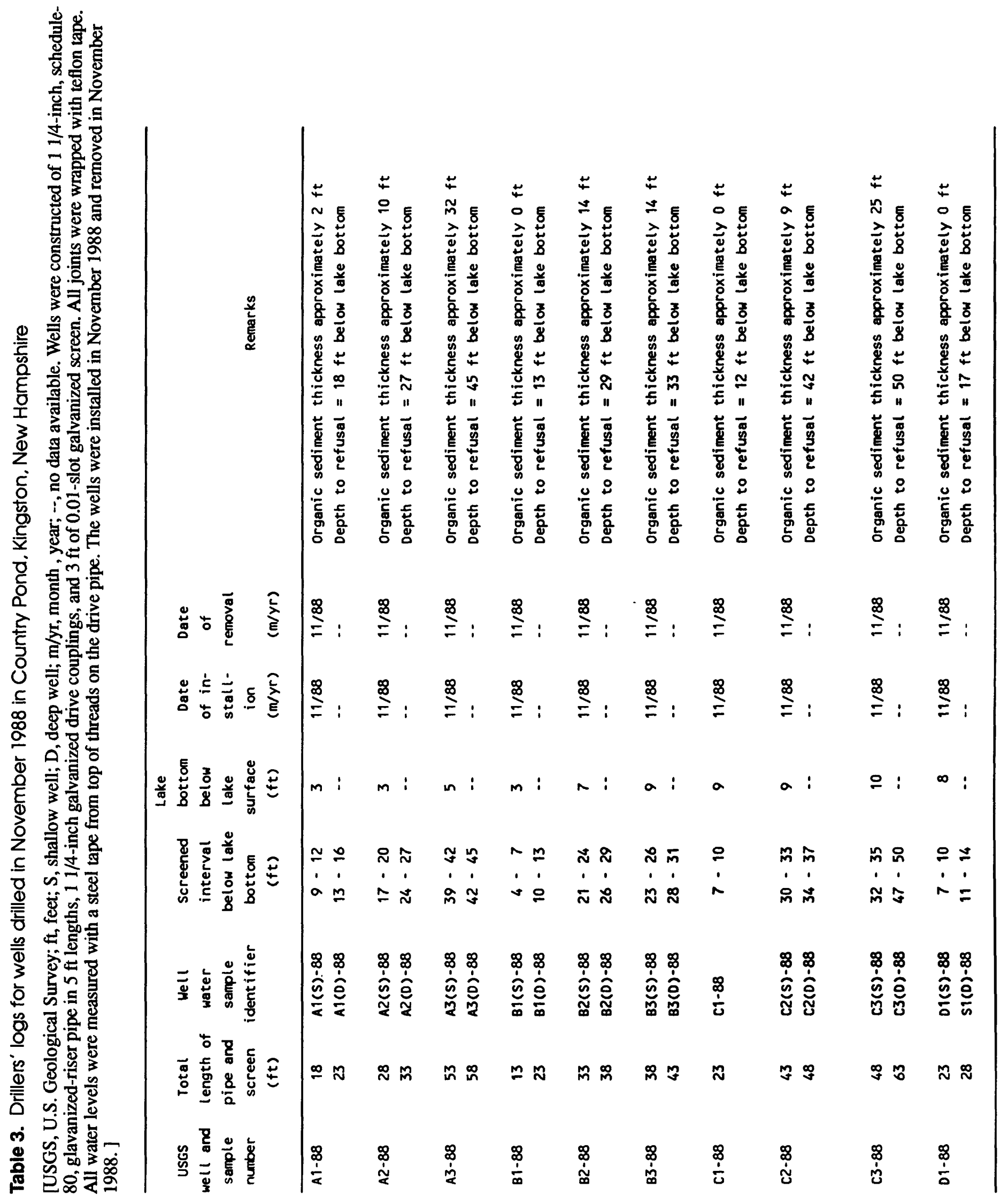




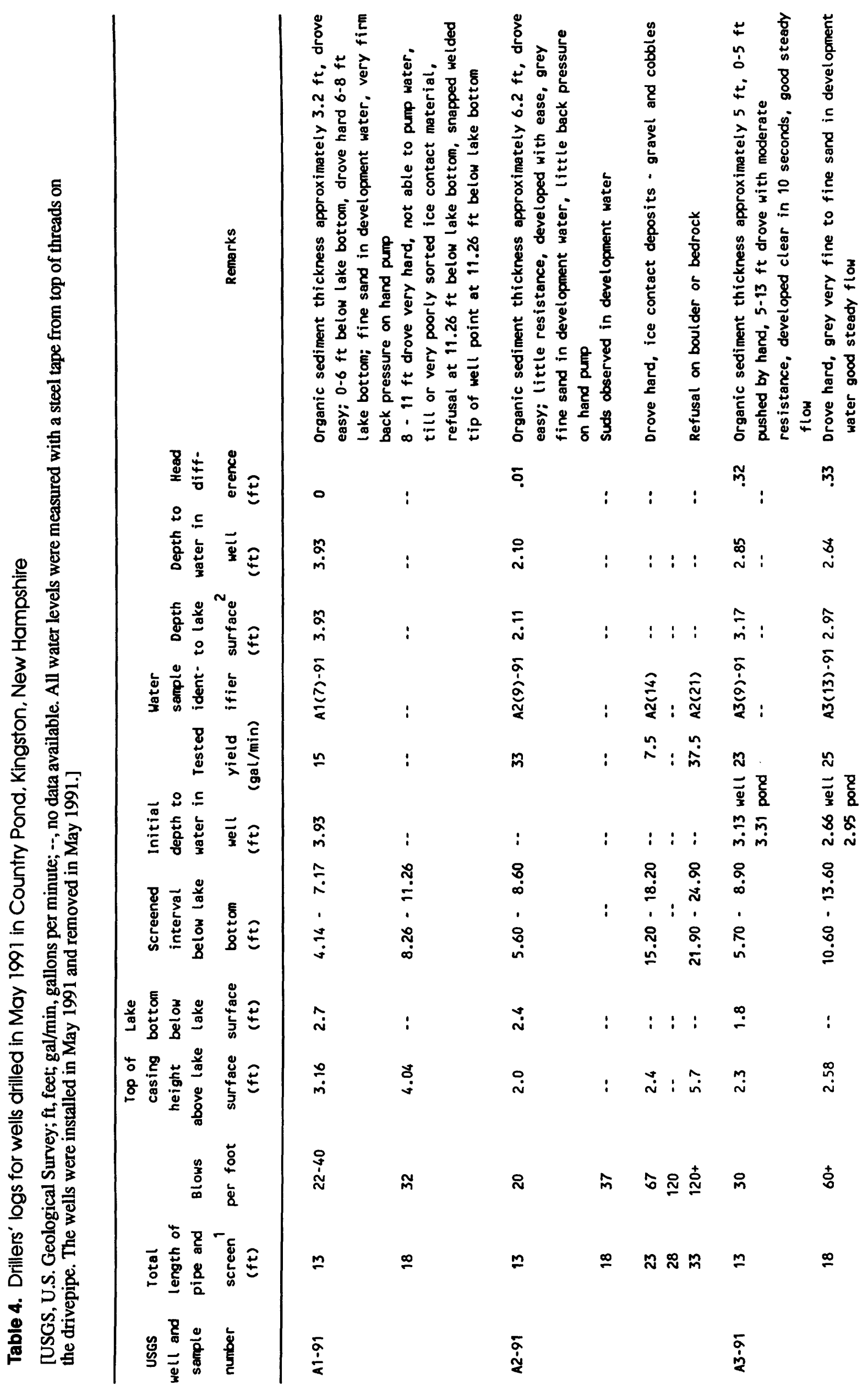




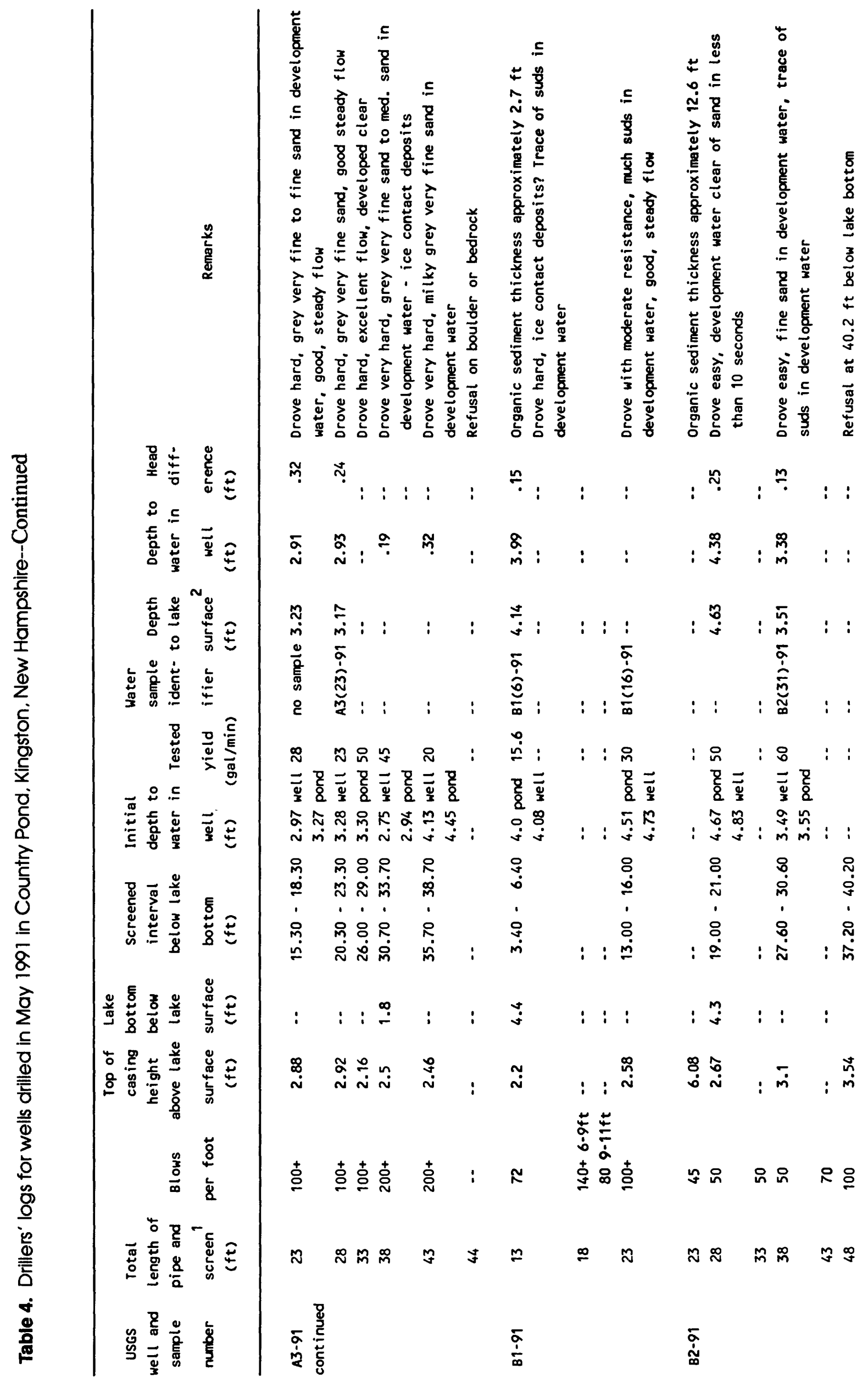




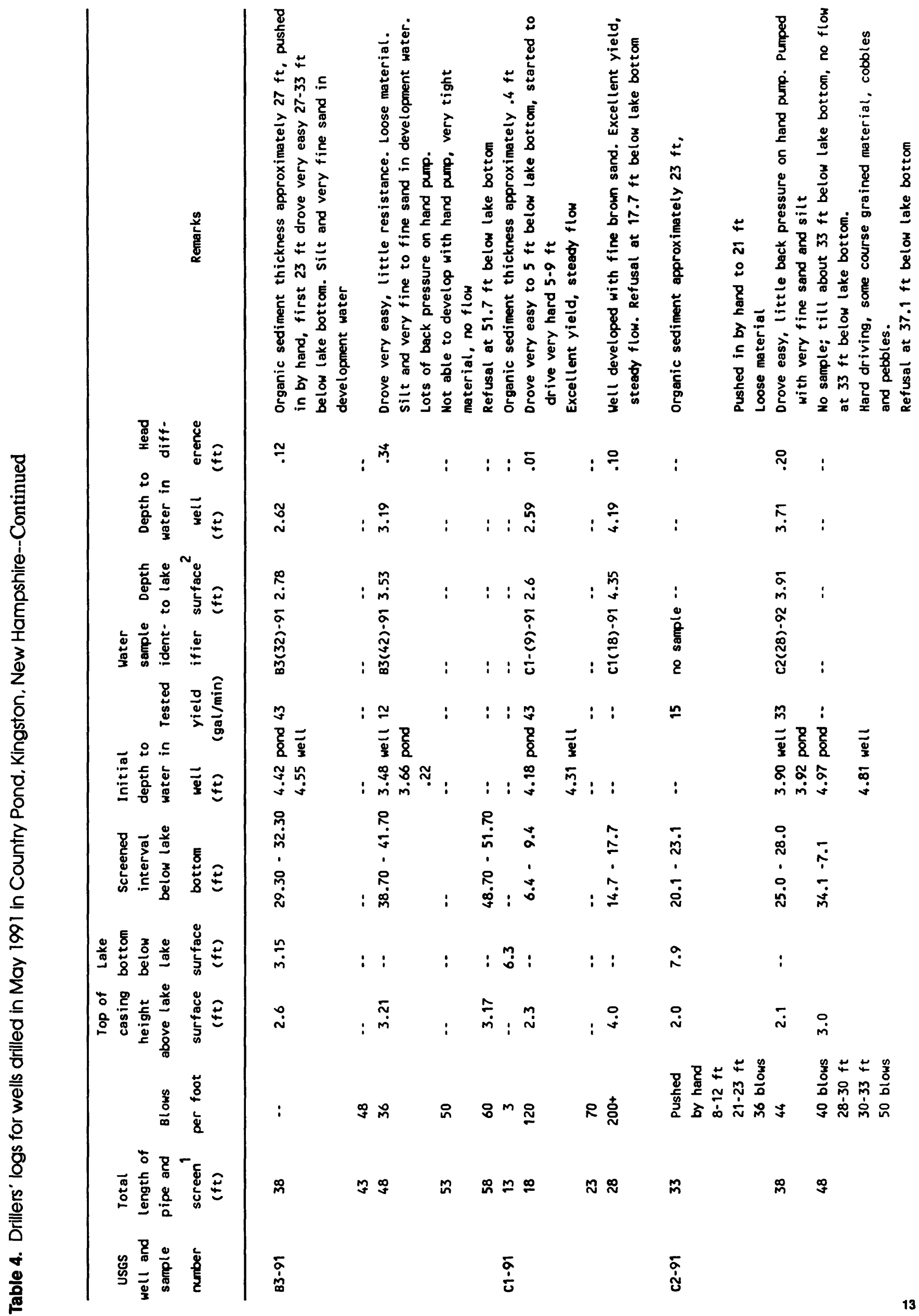




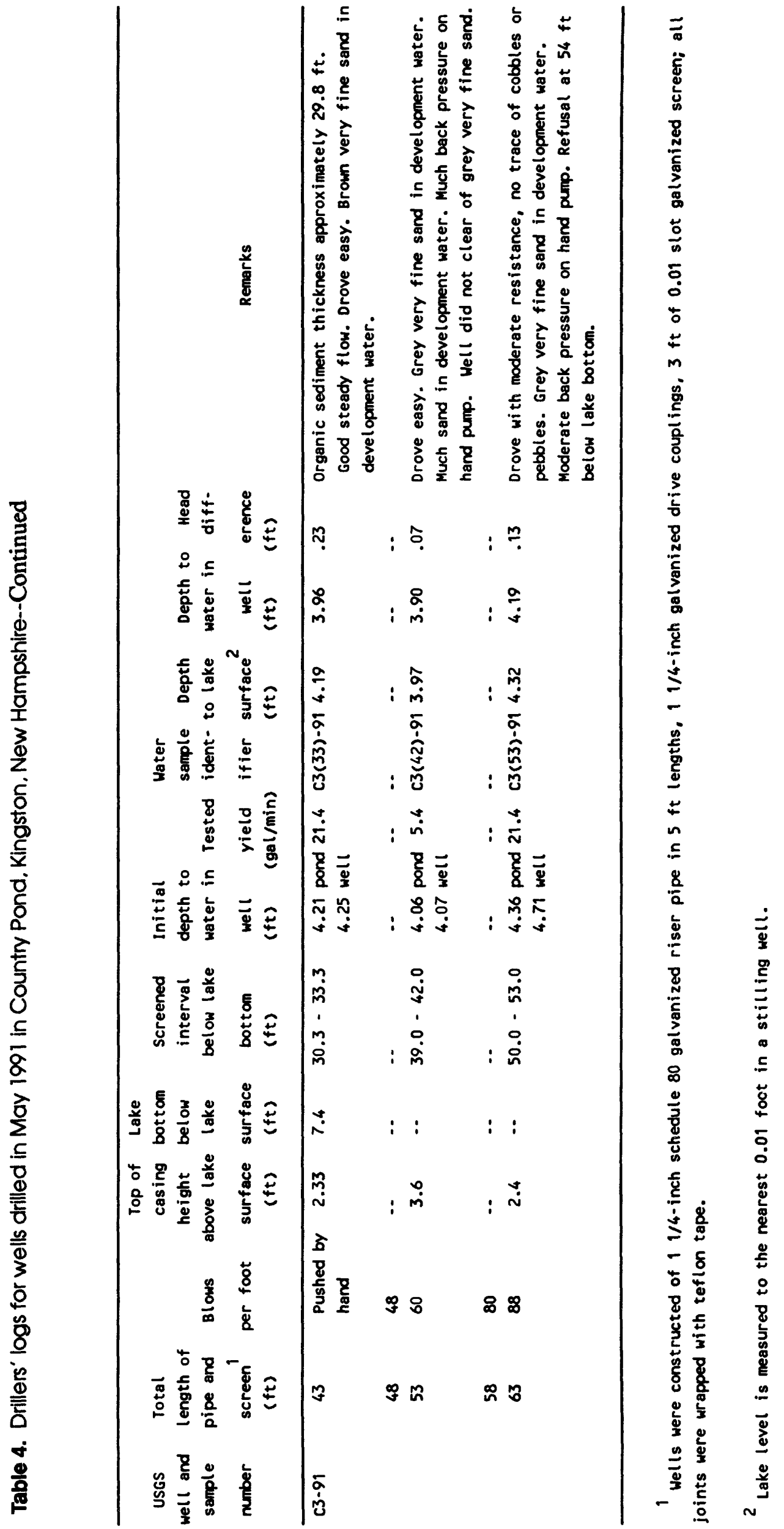




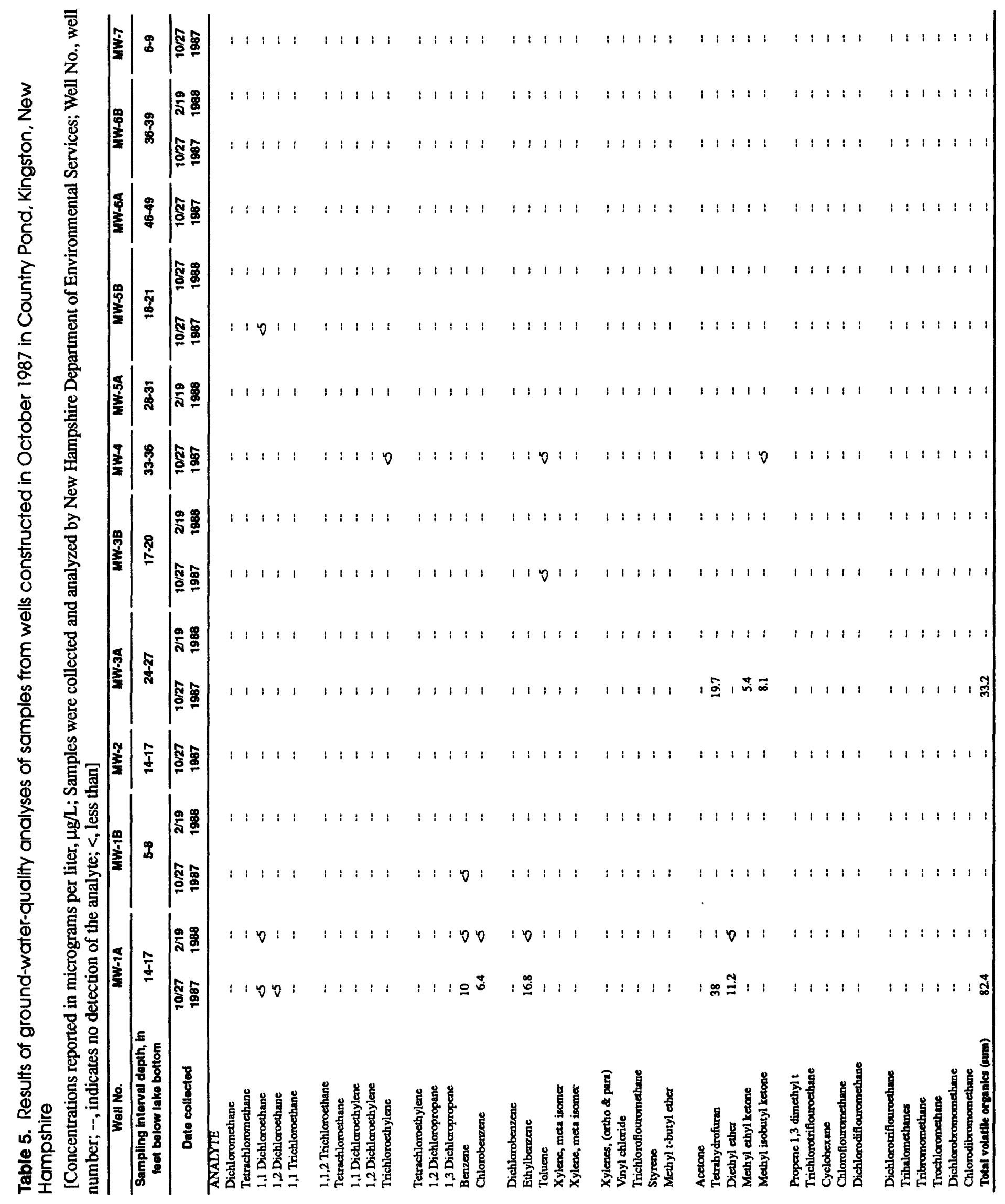




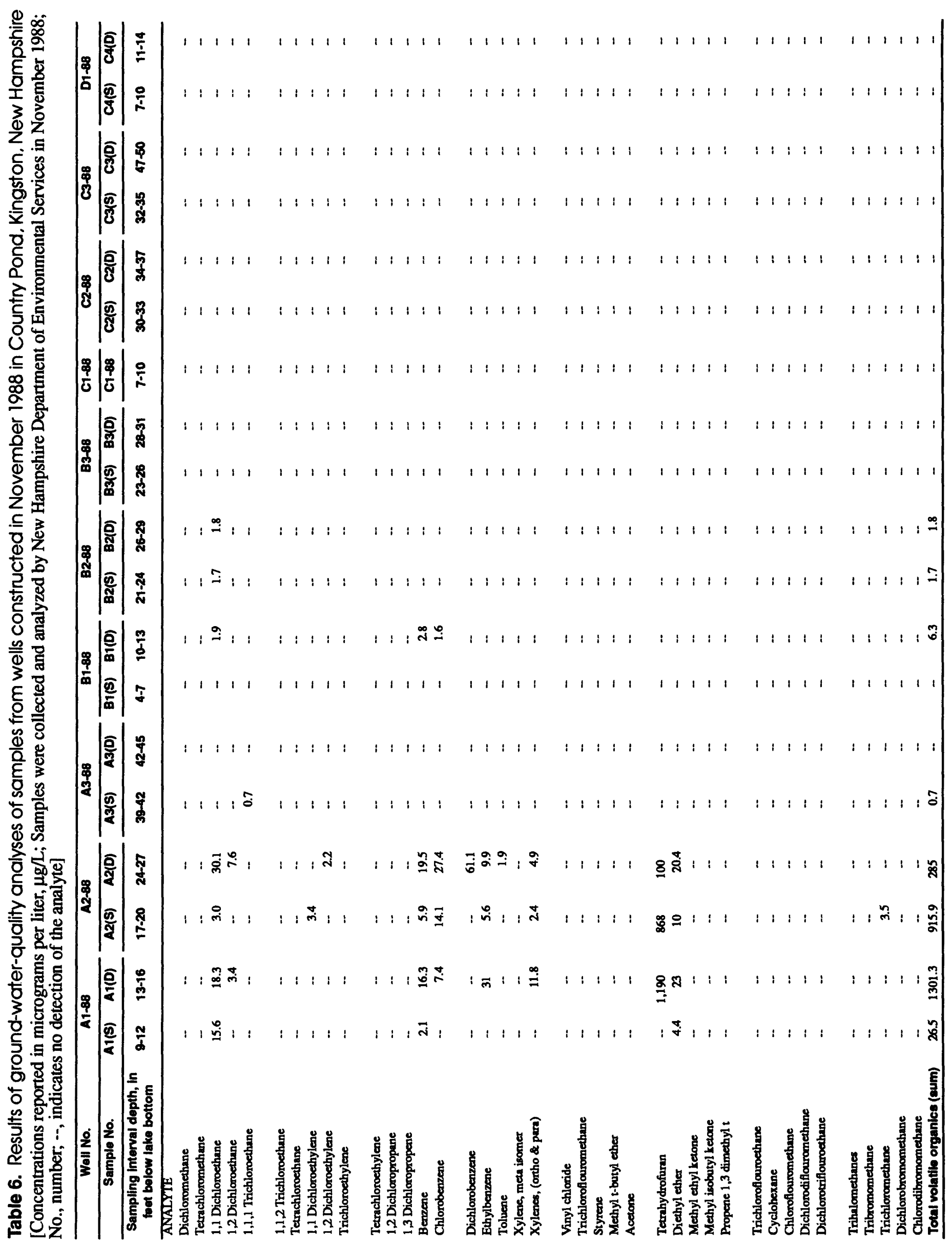




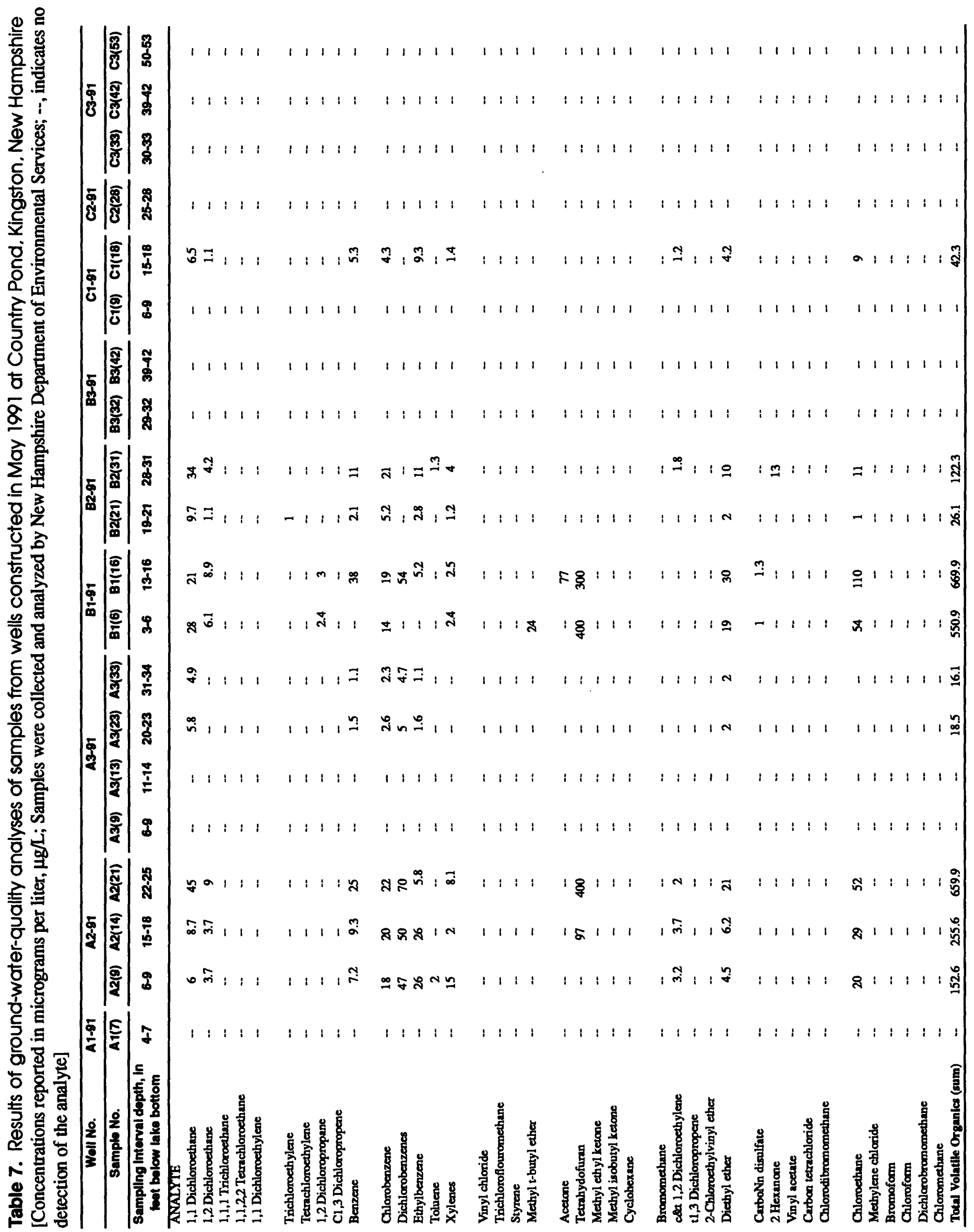


Table 8. Results of ground-water-quality anaylses for two wells sampled at Country Pond. Kingston, New Hampshire

[Concentrations reported in micrograms per liter, $\mu \mathrm{g} / \mathrm{L}$; samples were collected by Goldberg-Zoino, Associates and analyzed by New Hampshire Department of Environmental Services; well no., well number; --, indicates no detection of the analyte. Well No. GZ-1: Sampling interval depth of 1.2-31.5 feet below lake bottom. Well No. GZ-5: Sampling interval depth of 8-37.5 feet below lake bottom. Collection dates: Sample No. 1, November 1983; Sample No. 2, December 1983; Sample No. 3, January 1985]

\begin{tabular}{|c|c|c|c|c|c|c|}
\hline \multirow[t]{2}{*}{ ANALYTE } & \multicolumn{3}{|c|}{$\begin{array}{c}\text { Well No. GZ-1 } \\
\text { Sample No. }\end{array}$} & \multicolumn{3}{|c|}{$\begin{array}{c}\text { Well No. GZ-5 } \\
\text { Sample No. }\end{array}$} \\
\hline & 1 & 2 & 3 & 1 & 2 & 3 \\
\hline Dichloromethane & -- & -- & - & -- & -- & -- \\
\hline Chlorodibromomethane & -- & -- & -- & -- & -- & -- \\
\hline Dichlorobromomethane & -- & -- & -- & -- & -- & - \\
\hline Tribromomethane & -- & -- & - & -- & -- & -- \\
\hline Trichloromethane & -- & -- & - & -- & -- & -- \\
\hline Tetrachloromethane & -- & -- & -- & -- & -- & - \\
\hline Chloroethane & -- & -- & -- & -- & -- & - \\
\hline 1,1-Dichloroethane & -- & -- & -- & 92 & 106 & 63 \\
\hline 1,2-Dichloroethane & -- & -- & -- & - & $<10$ & $<5$ \\
\hline 1,1,1-Trichloroethane & -- & -- & - & -- & -- & -- \\
\hline 1,1,2-Trichloroethane & -- & -- & - & -- & - & - \\
\hline 1,1,2,2-Tetrachloroethane & -- & -- & - & -- & -- & -- \\
\hline 1,1-Dichloroethylene & -- & -- & - & -- & -- & -- \\
\hline Trans-dichloroethylene & -- & -- & - & -- & $<10$ & -- \\
\hline Trichloroethylene & -- & -- & - & -- & -- & -- \\
\hline Tetrachloroethylene & -- & -- & - & -- & -- & - \\
\hline 1,2-Dichloropropane & -- & -- & - & -- & -- & - \\
\hline 1,3-Dichloro $(c \& t)$ propene & -- & -- & - & -- & -- & -- \\
\hline Benzene & -- & -- & $<5$ & 19 & 17 & 15 \\
\hline Chlorobenzene & - & -- & - & 13 & $<10$ & 10 \\
\hline Dichlorobenzene & -- & -- & -- & 33 & - & 15 \\
\hline Ethylbenzene & -- & -- & -- & 26 & 17 & $<5$ \\
\hline Toluene & -- & -- & $<5$ & -- & - & $<5$ \\
\hline \multicolumn{7}{|l|}{ Xylenes } \\
\hline $\mathbf{M}$ isomer & -- & -- & - & 33 & 19 & -- \\
\hline O \& P isomer & -- & -- & - & 16 & -- & 13 \\
\hline Acetone & -- & -- & -- & - & -- & - \\
\hline Methyl Ethyl Ketone & -- & -- & -- & -- & 106 & 35 \\
\hline Methyl Isobutyl Ketone & -- & -- & - & -- & -- & -- \\
\hline Tetrahydrofuran & -- & -- & - & - & 264 & 29 \\
\hline Diethyl Ether & -- & -- & -- & -- & 11 & $<5$ \\
\hline Total volatile organics (sum) & -- & -- & $<5$ & 232 & 540 & 180 \\
\hline
\end{tabular}

